\section{REFLECTIONS ON THE EVOLUTION OF MODERN FINANCIAL SCIENCE}

\section{O G Dayaratna-Banda}

Department of Economics and Statistics

University of Peradeniya

\section{PERSPECTIVES}

Sri Lanka Journal of

Economic Research

Volume 2 (1)

June 2014: 108-119

Sri Lanka Forum of

University Economists

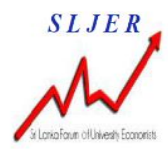

\title{
Abstract
}

Financial science or financial economics, as a sub-discipline in economics, has recorded a remarkable progress during the past fifty years. Finance deals with allocation of various assets and liabilities in the long run within uncertain conditions. Hence, the study of finance involves inquiring, explaining and predicting a diverse and growing number of financial instruments, institutions, and markets, as well as the relationship of their behavior to other economic variables. The study of finance has, therefore, become a study of human civilizations, progress, and even crises. This essay traces the key milestones of the evolution of financial science evaluating the path-breaking contributions to economic science made during a few decades. It attempts to highlight how the study of finance is useful in understanding and predicting human behavior as financial science has generated an extremely rich and rigorous body of theoretical, methodological and empirical knowledge which has increasingly become influential on the thought process of mainstream economics.

Key Words: Financial economics, Financial instruments and Human behavior 


\section{INTRODUCTION}

Finance has often been an elusive and highly debated thing in the affairs of human economic activities. In early human societies, money was not in any significant way linked to the performance or progress of humankind. Before the emergence of fiat money, various metals and materials were used as money which played the roles of medium of exchange and store of value. In such contexts, progress of human societies was not influenced by money, but by human efforts. However, money, banking and finance, derived/related products of money, have been thought to significantly influence human economic activity since the emergence of fiat money in different civilizations. Finance is a form of manifestation of money in relation to human economic activity involving trading of financial instruments in the context of risk and uncertainty. It deals with allocation of various assets and liabilities in the long run within the uncertain conditions. Finance, therefore, in most ways, relates to how money is used for human economic activity in future time periods under risks and uncertainty. Defining and explaining finance, one of the Nobel Laureates in Economics, Robert Shiller states that "finance and insurance are about an uncertain future . . . It is about managing it, and sharing your risks, hedging your risks... Finance is not about beating the market, necessarily. It is about managing risks in such a way that we can be a productive society and we can achieve our goals" (Shiller 2014).

From the period of classical political economy to the aftermath of the Great Depression in 1920s, financial science was not known in any significant way in the economics literature though the function of money and its various manifestations have been treated in economic theory and policy. Early economics literature integrated money and banking into the mainstream theory and policy, but very little of finance. However, in the early economic literature, the role of financial capital has been exposited. Schumpeter's work on creative destruction and the dynamic evolutionary nature of capitalist system (Schumpeter 1934) highlights the role of finance in the process of socio-economic change. Initial efforts in financial science have focused more on analyzing and predicting the behavior of securities exchange markets. However, financial innovations resulting from the deepening and expansion of markets around the world gave space for the development of the financial science as a sub-discipline in economics. The focus on finance came to the forefront of the economic discourse beginning from the seminal work of Harry Markowitz who later won the Nobel Economics Prize for his contribution to the development of financial science.

This brief essay traces the key milestones of the evolution of modern financial science as a prominent sub-discipline in economics that has made vital contributions to the development of thought and empirical methods in economics. We will highlight the most significant contributions to the advancement of financial science during the past few decades. This brief essay is justified on the premise that most undergraduate and postgraduate study programmes in economics in Sri Lanka have paid a scant attention to 
the advancement of financial science and its significant contributions to the development of mainstream economic theory and empirical methods. Though financial science has been developed by mainstream economics, the discipline has been left to the business or management schools in Sri Lanka. Economics degree programmes have rarely integrated financial science as an essential component of the skills and knowledge embodied in our graduates. It is also the case that much of the economic literature that we delivered to the undergraduate and postgraduate students through our programmes are highly dominated by theory and empirics developed in the context of certainty conditions, though theory and methods in financial science have made significant advancements in explaining markets and predicting the behavior of markets under risks and uncertainty. Teaching and promoting research in financial science in the undergraduate and postgraduate study programmes in economics would significantly enrich other sub-disciplines of economics. Financial science lends significant theoretical and methodological insights for the advancement of mainstream economics.

\section{RAPID DEVELOPMENT OF MODERN FINANCIAL SCIENCE SINCE 1950S}

The process of financial innovations has resulted in creating various financial products and markets. According to the Investopedia, finance is defined as "advances over time in the financial instruments and payment systems used in the lending and borrowing of funds. These changes - which include innovations in technology, risk transfer and credit and equity generation- have increased available credit for borrowers and given banks new and less costly ways to raise equity capital." It can also be defined as the act of creating and then popularizing new financial instruments as well as new financial technologies, institutions and markets. It includes institutional, product and process innovation. Institutional innovations relate to the creation of new types of financial firms. Financial innovations have led to developing various financial instruments that include debt, equity and foreign exchange instruments. Long term debt securities include bonds, loans, bond futures, bond options, interest rate swaps, interest rate caps and floors, interest rate options, and exotic derivatives. Short term debt instruments include bills, commercial papers, certificate of deposits, interest rate futures, and forward rate agreements. Equity instruments include stocks, stock options, equity futures, and exotic derivatives. Foreign exchange instruments include spot foreign exchange, currency futures, foreign exchange options, outright onwards, foreign exchange swaps, and currency swaps. Development of these various financial instruments that resulted in creating new institutions and markets compelled economists to undertake rigorous research about them. The emergence of financial instruments, institutions and markets paved the way for generating a significant body of new knowledge in the area of finance creating the distinct discipline known now as financial economics or financial science.

In the 1950s, much of the research in financial science focused on analyzing and forecasting the behavior of stock markets, and how to deal with risks in stock markets. 
The conventional wisdom in finance was that once one attains competency in investment decisions in stock markets, risk management and mitigation, by way of diversification, is undesirable. Therefore, one has to buy one or two, or at most three or four securities in order to maximize profits. It was thought that competent investors would never be satisfied beating the averages by a few small percentage points. In the paper entitled, The Battle for Investment Survival, Gerald M. Loeb (1935) analyzed securities one-by-one focusing on picking winners. It was emphasized to concentrate holdings to maximize returns. Broad diversification of securities was considered undesirable during this period. Financial science at the initial stage was, therefore, more of practical analysis of capital markets to assist investors rather than a rigorous academic discipline.

In mid 1950s, attention of researchers of capital markets moved towards bundling of various securities for diversification of risks. These bundles of securities, termed portfolios, were viewed in light of risks and returns. Harry Markowitz (1952, 1959), who won Nobel Prize in Economics in 1990 for his work on portfolio selection, emphasized that diversification of assets held by an investor tends to reduce risks by analyzing the portfolio risk versus security risk. Assets were evaluated by their effects on portfolio. Then, an optimal portfolio can be constructed to maximize return for a given level of risks measured by standard deviation. Harry Markowitz's pioneering work immensely contributed to the development of modern financial science.

James Tobin, who also won the Nobel Prize for his work, advanced Markowitz's seminal work much further by developing ideas related to the role of stocks mainly in his Separation Theorem in which he articulated that investors must form portfolio of risky assets and temper risk by lending and borrowing. His work shifted the focus from stock selection to portfolio structure. Tobin drew heavily from Keynes's work on liquidity preference in developing his own work (Tobin 1958).

Merton Miller (1986, 1991) and Franco Modigliani (1944) expanded the scope of finance research through their work on investments and capital structure. Among other things, their work is known as Modigliani-Miller Theorem (M\&M Theorem). The theorem relates corporate finance to returns. They found that a firm's value is unrelated to its dividend policy. Dividend policy is an unreliable guide for stock selection. The work of M\&M led to the emergence of another sub-discipline in economics, currently occupied in management/business schools, known as corporate finance. Their analysis lends much to the fact that how firm level actions and decisions affect the risks and returns of assets or portfolios of assets.

William Sharpe, who also won the Nobel Prize in Economics, focused, in his seminal work on analyzing the single factor asset pricing risk and return modeling. He developed the capital asset pricing model through which he explains the link between different types of assets, risks and returns. He defined risk as volatility relative to market. A stock's cost of capital (the investor's expected return) is proportional to the 
stock's risk relative to the entire stock universe. This is a theoretical model for evaluating the risk and expected return of securities and portfolios (Sharpe 1963, 1964, 1970, 1987). Sharpe has been a pioneer in developing financial science.

Paul Samuelson (1965), who won the Nobel Prize in Economics in 1970, counts, among his numerous contributions to economics an examination of the behavior of securities prices. He emphasized that market prices are the best estimates of value. Price changes follow random patterns. According to Samuelson, future stock prices are unpredictable. The Concise Encyclopedia of Economics states that "in finance theory, which he [Samuelson] took up at age fifty, Samuelson did some of the initial work that showed that properly anticipated futures prices should fluctuate randomly. Samuelson also did path breaking work in capital theory..." These contributions made a significant contribution to the latter theoretical developments in financial science. The work of Robert Merton and William Sharpe has also significantly been influenced by the Samuelson's work.

Information efficiency is vital to the success of the capital markets as decisions have to be taken based on all available information. This particular aspect of the financial markets was seriously addressed by Eugene F. Fama (1965, 1972, 1976), who also won the Nobel Prize in Economics for his work on finance, in his seminal work on efficient market hypothesis. Fama's work has significantly been influenced by the contribution of Samuelson. He conducted extensive research on stock price patterns. Fama distinguished between three types of efficiencies, namely, weak form efficiency, semistrong form efficiency, and strong form efficiency, under three different sets of information available to the investors. He extended earlier work on unpredictability of stock prices and finds that prices quickly incorporate information. He argued that if investors use past information to make predictions, markets are only weak form efficient. If investors do have access to past and current public information, markets become semi-strong form efficient. When investors use all available information markets become strong form efficient meaning that no single individual is able to make a different prediction about the future behavior of stock prices from what the average investor is able to foresee. He developed "Efficient Markets Hypothesis," which asserts that prices reflect values and information accurately and quickly. It is difficult, if not impossible, to capture returns in excess of market returns without taking greater than market levels of risk. Investors cannot identify superior stocks using fundamental information. In practice, however, there is no perfect information situation in any market meaning that future securities prices can be predicted by using various past and current information available (Vidanage and Dayaratna-Banda 2012 and 2013).

In the late 1960s, researchers also began inquiring into the performance of managers and how that tended to determine the risks and returns. Michael Jensen (1965) and A.G. Becker Corporation (1968) have conducted in depth research into the nexus between financial market performance and manager performance. First Jensen studied mutual 
funds and A.G Corporation institutional plans indicating that active managers underperform indexes. Becker Corporation gives rise to consulting industry with creation of "Green Book" performance tables comparing results to benchmarks. First studies showing investment professionals fail to outperform market indexes. Jensen specifically analyzed the role of fund managers in managing mutual funds.

In early 1970s, Chicago University researchers began to inquire into the derivative pricing models, especially focusing on option pricing. These researchers include Fisher Black and Myron Scholes of University of Chicago and Robert Merton of Harvard University, who also won the Nobel Prize in Economics in 1997. The development of the Option Pricing Model allows new ways to segment, quantify and manage risk. It spurs the development of a market for alternative investments. Their work was mainly focused on highly risky derivative securities. Option pricing under risk and uncertainty open various new theoretical avenues for researchers to inquire into human behavior under conditions of uncertainty and risks (Black 1975, 1976, 1986, 1987; Black and Scholes 1973, 1974; Merton 1973).

The link between random prices and practical investing was inquired into by John McQuown and Rex Sinquefield (1963). This led to the birth of index funds and Wells Fargo Bank which have developed the first passive S\&P 500 Index funds. Years later, Sinquefield chaired Dimensional and McQuown sat on its Board. Dimensional further develops passive and structured investment strategies. A major plan first committed to indexing of prices began in 1975. New York Telephone Company invests \$ 40 million in an S\&P 500 Index fund. The first major plan to index helped launch the era of indexed investing. "Fund spokesmen are quick to point out you cannot buy the market averages, and it is time the public could" (Burton G. Malkiel 1973). In order to facilitate this process, database of securities prices were developed. In 1977 Roger Ibbotson \& Rex Sinquefield in an article entitled "Stocks, Bonds, Bills and Inflation", an extensive returns database for multiple asset classes was first developed which would become one of the most widely used investment databases. This is the first extensive, empirical basis for making asset allocation decisions changes the way investors build portfolios.

The effect of the size on risks and returns was also examined by Rolf Banz (1981). He analyzed New York Stock Exchange stocks from 1926 to 1975 and found that, in the long term, smallest companies had largest expected returns. Small companies behave differently from large companies and deserve stronger than market representation. International size effects were incorporated since 1986. This led to structured investing versus indexing. Dimensional Fund Advisors Inc. created a structured product in an undiscovered asset class. Dimensional product returns become the index used in Ibbotson Associates' database. Structured investing is innovative. It is based on a rational risk dimension, and does not slavishly follow indexes or investing conventions. 
Eugene Fama and Kenneth French (1992) developed the multi-factor asset pricing model to explain the value effects. They improved on the single factor asset pricing model (CAPM) developed earlier by William Sharpe. They identified market, size and value factors in determining returns for securities. Fama and French further developed the three-factor asset pricing model, an invaluable asset allocation and portfolio analysis tool. They revolutionized the way we construct and analyzed portfolios by identifying independent sources of risk and return. They also introduced the first concentrated, empirical value strategies, which led to similar findings internationally.

Financial science over the last fifty years has brought us to a powerful understanding of the risks that are worth taking and the risks that are not. Three equity factors market included: stocks which have higher expected returns than fixed income, size which means that small company stocks have higher expected returns than large company stocks, price which means that lower-priced "value stocks" have higher expected returns than higher-priced "growth stocks".

Everything about expected returns in the equity markets can be summarized in three dimensions. The first is that stocks are riskier than bonds and have greater expected returns. Relative performance among stocks is largely driven by the two other dimensions: small/large and value/growth. Many economists believe small cap and value stocks outperform because the market rationally discounts their prices to reflect underlying risk. The lower prices give investors greater upside as compensation for bearing this risk. Applied core equity dimensional portfolio construction methodology weights securities by size and value characteristics instead of market capitalization. Total market strategies launched to provide efficient, diversified risk factor exposure while limiting turnover and transaction costs. Core equity portfolios move beyond traditional, component-based asset allocation via vast diversification and cost-efficient market coverage. Theory and policy in other sub-disciplines of economics are yet to incorporate analysis of human economic behavior under risks and uncertainty even though some advancement has taken place in recent times in macroeconomics.

The central premise that financial science as a subject holds in economics is more evident from the number of Nobel Memorial Prizes in Economics awarded to those who have been doing research on finance or on finance-related fields. Since the introduction of Nobel Memorial Prize in Economics in 1969, nearly thirty Nobel laureates have emerged from the area of finance or finance-related fields in economics (Table 1). Research on finance has contributed a great deal to the advancement of econometrics as quantitative methods widely applied in economic research. Most research developments in macroeconomics and microeconomics have also been highly influenced by the recent development of knowledge in financial science. The 2014 Nobel Prize in Economics was awarded to Jean Tirole whose theoretical and empirical work in microeconomics focusing on market power and regulating to tame big firms has heavily relied on financial markets and institutions for his analysis. 
Table 1: Nobel Memorial Prize in Economics for Finance and Finance Related Research

\begin{tabular}{|c|c|c|c|c|}
\hline & Year & Laureate & Nobel Citation & Field \\
\hline 1 & 1970 & Paul Samuelson & $\begin{array}{l}\text { "for the scientific work } \\
\text { through which he has } \\
\text { developed static and dynamic } \\
\text { economic theory and actively } \\
\text { contributed to raising the level } \\
\text { of analysis in economic } \\
\text { science" }\end{array}$ & $\begin{array}{l}\text { Finance in } \\
\text { microeconomics }\end{array}$ \\
\hline 2 & 1981 & James Tobin & $\begin{array}{l}\text { "for his analysis of financial } \\
\text { markets and their relations to } \\
\text { expenditure decisions, } \\
\text { employment, production and } \\
\text { prices" }\end{array}$ & $\begin{array}{l}\text { Finance in } \\
\text { macroeconomics }\end{array}$ \\
\hline 3 & 1985 & Franco Modigliani & $\begin{array}{l}\text { "for his pioneering analyses } \\
\text { of saving and of financial } \\
\text { economics" }\end{array}$ & $\begin{array}{l}\text { Finance in } \\
\text { macroeconomics }\end{array}$ \\
\hline 4 & 1990 & $\begin{array}{l}\text { Harry Markowitz } \\
\text { Merton Miller } \\
\text { William Sharpe }\end{array}$ & $\begin{array}{l}\text { "for their pioneering work in } \\
\text { the theory of financial } \\
\text { economics" }\end{array}$ & $\begin{array}{l}\text { Financial } \\
\text { economics }\end{array}$ \\
\hline 5 & 1996 & $\begin{array}{l}\text { James Mirrlees } \\
\text { William Vickrey }\end{array}$ & $\begin{array}{l}\text { "for their fundamental } \\
\text { contributions to the economic } \\
\text { theory of incentives under } \\
\text { asymmetric information" }\end{array}$ & $\begin{array}{l}\text { Financial } \\
\text { Economics }\end{array}$ \\
\hline 6 & 1997 & $\begin{array}{l}\text { Robert Merton } \\
\text { Myron Scholes }\end{array}$ & $\begin{array}{l}\text { "for a new method to } \\
\text { determine the value of } \\
\text { derivatives." }\end{array}$ & $\begin{array}{l}\text { Financial } \\
\text { Economics }\end{array}$ \\
\hline 7 & 1999 & Robert Mundell & $\begin{array}{l}\text { "for his analysis of monetary } \\
\text { and fiscal policy under } \\
\text { different exchange rate } \\
\text { regimes and his analysis of } \\
\text { optimum currency areas" }\end{array}$ & $\begin{array}{c}\text { Finance in } \\
\text { international } \\
\text { macroeconomics }\end{array}$ \\
\hline 8 & 2000 & Daniel McFadden & $\begin{array}{l}\text { "for his development of } \\
\text { theory and methods for } \\
\text { analyzing discrete choice" }\end{array}$ & $\begin{array}{l}\text { Banking and } \\
\text { Finance }\end{array}$ \\
\hline 9 & 2001 & $\begin{array}{l}\text { George Akerlof } \\
\text { Michael Spence } \\
\text { Joseph E. Stiglitz }\end{array}$ & $\begin{array}{l}\text { "for their analyses of markets } \\
\text { with asymmetric information" }\end{array}$ & $\begin{array}{l}\text { Banking and } \\
\text { finance }\end{array}$ \\
\hline 10 & 2003 & Robert F. Engle & "for methods of analyzing & Finance in \\
\hline
\end{tabular}




\begin{tabular}{|c|l|l|l|c|}
\hline \multirow{2}{*}{11} & & $\begin{array}{l}\text { economic time series with } \\
\text { time-varying volatility } \\
\text { (ARCH)" }\end{array}$ & econometrics \\
\cline { 3 - 6 } & \multirow{2}{*}{2010} & $\begin{array}{l}\text { "for methods of analyzing } \\
\text { economic time series with } \\
\text { Common } \\
\text { (cointegration)" }\end{array}$ & $\begin{array}{l}\text { Finance in } \\
\text { econometrics }\end{array}$ \\
\hline 12 & $\begin{array}{l}\text { Christopher } \\
\text { Pissarides }\end{array}$ & $\begin{array}{l}\text { (for their analysis of markets } \\
\text { with search frictions" }\end{array}$ & $\begin{array}{c}\text { Finance in } \\
\text { microeconomics } \\
\text { and }\end{array}$ \\
\hline 13 & $\begin{array}{l}\text { Eugene F Fama } \\
\text { Lars Peter Hansen } \\
\text { Robert J. Shiller }\end{array}$ & $\begin{array}{l}\text { "for their empirical analysis } \\
\text { of asset prices." }\end{array}$ & $\begin{array}{c}\text { Financial } \\
\text { economics }\end{array}$ \\
\hline
\end{tabular}

\section{CONCLUDING REMARKS}

The study of money, banking and finance has played varying roles, though pivotal, in shaping the theory and practice of modern economics. From the periphery of economic thought in early years of modern economics, the study of money, banking and finance has increasingly occupied a central premise in economic thought. Advancement of financial science as a distinct discipline has provided significant insights into the development of other sub-disciplines of economics. It has served as a platform for building economic theory in various sub-disciplines, staggering advancements in empirical methods in economics. Financial science has also increasingly become a vital policy tool in modern societies. Financial science is occupying a central place in mainstream economic theory and policy. Some have even suggested theoretically that finance literacy can be considered a capital serving as a vital input in production suggesting that human progress tends to depend also on, among other things, whether people are literate about finance or not. The study of finance has also gone beyond economics and has increasingly influenced the thought process of other disciplines in human sciences. However, financial science has not been given its central premise in economics study programmes and research in Sri Lanka. It is vital that we attempt to mainstream financial science in economics to provide a new leaf of valuable life to economics for analyzing human economic behavior under risks and uncertainty.

\section{REFERENCES}

Banz Rolf (1981). The relationship between return and market value of common stock, Journal of Financial Economics, 9: 3-18 
Black, F. (1975). Fact and Fantasy in the Use of Options. Financial Analysts Journal 31, pp36-41, 61-72 (July/August).

Black, F. (1986). Noise. Journal of Finance, 41, 529-543.

Black, F. (1987). Business Cycles and Equilibrium, Basil Blackwell.

Black, F. and Scholes, M. (1974). The Effects of Dividend Yield and Dividend Policy on Common Stock Prices and Returns. Journal of Financial Economics.

Black, F. and Scholes M. (1973). The Pricing of Options and Corporate Liabilities. Journal of Political Economy.

Black, F. (1976). The Pricing of Commodity Contracts. Journal of Financial Economics.

Black, F. (1995). Interest Rates as Options. Journal of Finance, 50, 1371-1376

Black, F. (1995). Exploring General Equilibrium, MIT Press.

Black, F. Scholes M., and Jensen M., (1972). The Capital-Asset Pricing Model: Some empirical tests, in Jensen, editor, Studies in the Theory of Capital Markets.

Fabozzi, Frank J. and Modigliani F.(1996). Capital Markets: Institutions and Instruments. Upper Saddle River, NJ: Prentice Hall.

Fama, Eugene F. (1972). The Theory of Finance, Dryden Press.

Fama, Eugene F. (1976). Foundations of Finance: Portfolio Decisions and Securities Prices, Basic Books.

Fama, Eugene F. (1965). "Random Walks in Stock Market Prices". Financial Analysts Journal 21 (5): 55-59.

Fama, Eugene F., Merton H. Miller (1972). The Theory of Finance New York: Holt, Rinehart \& Winston.

Fama, Eugene F and French, Kenneth R. (1993) Common Risk Factors in the Returns on Stocks and Bonds. Journal of Financial Economics 33 (1): 3-56.

Ibbotson, Roger and Rex Sinquefield (1977). Stocks, Bonds, Bills and Inflation. Charlottesville.

Jensen, Michael, (1965). The Performance of Mutual Funds in the period 1945-1964. Journal of Finance December.

Gerald, L. M. (1935/1996) The battle for Investment Survival. John Wiley and Sons. 
Malkiel Burton G. (1973). A Random Walk Down Wall Street (6 ${ }^{\text {th }}$ ed.). W.W. Norton \& Company, Inc.

Markowitz, H.M. (1952). Portfolio Selection. The Journal of Finance, 7 (1): 77-91.

Markowitz H.M. (1959). Portfolio Selection: Efficient Diversification of Investments. New York: John Wiley \& Sons.

Merton Robert C. (1973) "Theory of Rational Option Pricing". Bell Journal of Economics and Management Science (The RAND Corporation) 4 (1): 141-183.

Miller Merton H. (1991) Financial Innovations and Market Volatility. Cambridge, MA: Blackwell Publishing.

Miller Merton H. (1991) Merton Miller on Derivatives. New York: John Wiley \& Sons

Miller Merton, H.Charles W. Upton (1986). Macroeconomics: A Neoclassical Introduction. Chicago: University of Chicago Press

Modigliani, Franco (1944). Liquidity Preference and the Theory of Interest Rate and Money. Econometrica, Vol. 12, No. 1: 45-88

Modigliani, Franco (2001). Adventures of an Economist. London, New York: Texere

Modigliani, Franco; Andrew B Abel; Simon Johnson (1980). The Collected Papers of Franco Modigliani. Cambridge, Mass.: MIT Press

Samuelson Paul (1965). Proof That Properly Anticipated Prices Fluctuate Randomly. Industrial Management Review (Spring)

Schumpeter, Joseph A. (1934). The theory of economic development: an inquiry into profits capital, credit, interest, and the business cycle. New Brunswick, New Jersey

Sharpe W (1970/2000), Portfolio Theory and Capital Markets McGraw-Hill

Sharpe, W (1987). Asset Allocation Tools, Scientific Press.

Sharpe, W, Gordon J. Alexander and Jeffrey Bailey (2000. Fundamentals of Investments, Prentice-Hall

Sharpe, William F. (1963). A Simplified Model for Portfolio Analysis. Management Science 9 (2): 277-93.

Sharpe, William F. (1964). Capital Asset Prices - A Theory of Market Equilibrium Under Conditions of Risk. Journal of Finance XIX (3): 425-42. 
Shiller Robert (2014).This is What Finance Actually Is http://www.businessinsider.com/robert-shiller-explains-finance-2014-11. Downloaded on 25-11-2014

Tobin James (1958). Liquidity Preference as Behavior toward Risk. The Review of Economic Studies, February.

Vidanage T.N and O G Dayaratna-Banda. (2013). Factors Determining the Predictability of Stock Prices in Emerging Capital Markets: Evidence from Colombo Stock Exchange. Modern Sri Lanka Studies, Vol. IV, No 1

Vidanage, T. N and O G Dayaratna-Banda. (2012). Does Past Information Help Predict Future Price Movements in Emerging Capital Markets? Evidence from the Colombo stock exchange. South Asia Economic Journal, Vol. 13, no 2 